\title{
Survivability, growth performance and nutrient composition of the African Palm Weevil (Rhyncophorus phoenicis Fabricius) reared on Four different substrates
}

\author{
Ebenebe, C. I. ${ }^{1^{*}}$, Okpoko V. $0 .^{2}$, Ufele A. N. ${ }^{2}$ and Amobi M. I. ${ }^{2}$ \\ 1Department of Animal Science and Technology, Nnamdi Azikiwe University, Awka, P.M.B. 5025, Anambra State, \\ Nigeria. \\ 2Department of Zoology, NnamdiAzikiwe University, Awka, P.M.B. 5025, AnambraState, Nigeria. \\ *Corresponding author. Email: ci.ebenebe@unizik.edu.ng, ifynwagracee@gmail.com. Tel: +2348033924529.
}

Copyright @ 2017 Ebenebe et al. This article remains permanently open access under the terms of the Creative Commons Attribution License 4.0, which permits unrestricted use, distribution, and reproduction in any medium, provided the original work is properly cited.

Received 28th September, 2016; Accepted 24th November, 2016

\begin{abstract}
Survivability, growth performance and nutrient composition of the African Palm weevil (APW) (Rhyncophorus phoenicis) reared on four different substrates was investigated following earlier finding that Sugar cane tops (SCT) and Spoilt water melon (SWM) could be useful in captive rearing of the weevil. This necessitated a search into other waste fruits that could be used as media for rearing of APW as their infestation of oil and raffia palm is not only unfriendly to the environment but also wastage of economic resources. The growth and nutrient composition of the larvae in three waste fruits (Not rotten but not fit for human consumption): Spoilt Water Melon (SWM), Ripe Paw paw (RPP), Spoilt Pine apple (SPA) and Sugarcane tops (SCT: Off Cut from the tip of sugarcane) were compared in this study. One hundred and twenty newly emerged APW larvae of similar weights collected from "Mgbo swamp" in Ebenebe town, Anambra State, Nigeria, were used for the study which lasted for ten weeks. Thirty larvae were randomly assigned to each of the treatments (Culture media). The experiment was designed on a $4 \times 3$ Completely Randomized Designed, whereby each treatment had 30 APW larvae in three replicates of 10 larvae per replicate. The larvae were housed in plastic bowls of $30 \mathrm{~cm}$ diameter and $40 \mathrm{~cm}$ height. The bottom part of each bowl was perforated to let out moisture and the top covered with mosquito net to avoid flies. The substrates in each housing unit were removed and replaced with fresh ones on weekly basis to minimize microbial attack. Survivability, growth performance in terms of weight gain and increase in linear body measurements within 10 weeks were monitored and used as indices of the suitability of each of the culture media. At the end of the experiment three larvae were randomly selected from each replicate and taken to the Biochemistry Department Laboratory, Nnamdi Azikiwe University, Awka for proximate analysis. The result of statistical analysis showed that percent survivability was highest in Sugar cane top (96.7\%) and least in larva reared on Ripe Paw paws (66.7\%). The body weight and linear body measurement followed the same trend with those on SCT and SWM having the highest body weight increase of $4.13 \pm 0.11 \mathrm{~g}$ and $4.11 \pm 0.31 \mathrm{~g}$ respectively, while the ones on RPP had the least body weight increase of $2.7 \pm 0.06 \mathrm{~g}$. For the body length increase, the larva reared on SCT recorded $2.0 \pm 1.3 \mathrm{~cm}$, those on SWM recorded $1.8 \pm 0.23 \mathrm{~cm}$ and the ones on RPP had the least body length increase of $0.9 \pm 0.1 \mathrm{~cm}$. However, the crude protein percent of the larvae reared on SPA was highest $(25.90 \%)$, followed by those on SCT $(22.50 \%)$ and those on RPP recorded the least crude protein content of $21.25 \%$. It is therefore recommended that Discarded/Spoilt water melon, Sugar cane tops and discarded ripe pineapple be used in the rearing of the larvae up to 10 weeks or before pupation.
\end{abstract}

Key words: Rhncophorus phoenicis, survivability, growth performance, nutrient composition, substrates. 


\section{INTRODUCTION}

Insect protein has remained an unharnessed animal protein source (Ebenebe and Okpoko, 2015a) necessary to improve animal protein supply and consumption especially for animal protein deficient country like Nigeria. Mmadubuike (2000) showed the apparent failure of conventional meat protein in meeting animal protein needs in the country. Okoro (2000) reported animal protein intake in Nigeria to be 7 to $10 \mathrm{~g} /$ person/day against the recommended $34 \mathrm{~g} /$ person/day (FAO 1991). Ebenebe and Okpoko (2015) posited that edible insect farming and consumption (entomophagy) can be a major strategy for reducing animal protein deficiency in the country. Nutritional and other health benefits of edible insect has been documented by many authors ((Ekpo and Onigbinde 2004, Banjo et al., 2006, Ebenebe et al., 2007, Edijala et al., 2009). Edible insect consumption has been reported in most parts of Africa, Asia, America and even Europe. FAO/ WUR (2013) outlined common insects consumed globally, including beetles, grasshoppers, locusts and crickets. Consumption of larva of many insects has also been documented. FAO (2003) reported consumption of mopane caterpillar (Imbrasia belina) in Angola, Botswana, Mozambique, Namibia, South Africa, Zambia and Zimbabwe. Malaisse (1997) identified 38 different species of caterpillar consumed across the Democratic Republic of Congo, Zambia and Zimbabwe.

However, in most African countries, the unsustainable practice of wild collection, characterized by low yield and seasonality problems has remained the only means of harvesting the insects. For insects like APW collected from raffia palms (Plates 1 and 2) beside water bodies (river, stream, lakes), there is an environmentally orchestrated seasonality as the river banks are often flooded and make the swamps inaccessible when it rains. There is a need for alternative means of culturing the insects outside its natural habitat to ensure year round supply. Hoddle (2013) described two methods of rearing Red palm weevil ( $R$. ferrugineus) in Thailand: one involved grinding of the palm trunk and rearing the weevil in containers filled with ground palm log materials, the other involved direct use of the palm trunk, the methods though successful involved felling down of palm trees and therefore appears environmentally unfriendly. The method of mass rearing described by Kaakeh et al. (2001) for R. ferrugineus in the United Arab Emirate and the meridic diet for multiplication of $R$. ferrugineus by ElShafie et al. (2013) involved costly ingredients and appear too technical for the rural households in Africa and Nigeria in particular. Other authors have also described techniques for rearing of some weevil species (Giblin Davies et al., 2013; Bong et al., 2008 and Shashma et al., 2009). However, the use of agricultural waste for rearing of $R$. phoenicis is more tenable in Africa. Ebenebe and Okpoko (2016) reported the rearing of APW in eight different substrates (agricultural wastes) in Nigeria and discovered that the larva can survive in spoilt water melon and sugar cane. This study therefore assesses the survivability, nutrient composition and growth performance of the larva in sugar cane and three different fruits used as culture media (Substrates).

\section{MATERIALS AND METHODS}

The study was carried out at the Biological Conservation Unit of the Department of Zoology, Nnamdi Azikiwe University Awka, Anambra State, Nigeria. Anambra State lies between latitudes $7^{\circ} \mathrm{E}$ and $7^{\circ} 9^{1} \mathrm{E}$ and longitudes $6^{\circ} 6^{1} \mathrm{~N}$ and $6^{\circ} 17^{1} \mathrm{~N}$ while its geographical coordinates are 6०10'0" North, 7० 4' 0" East. One hundred and twenty African Palm Weevil (APM) Rhyncophorus phoenicis of similar weight were hand-picked from rotting raffia palms at "Mgbo area" of Ebenebe town in Awka North Local Government of Anambra State were used in this study.

The larvae were identified using the key provided by Giblin-Davies et al. (2013) who reported acutely tapered scutellum to be a distinguishing characteristic that differentiates R. phoenicis from other Rhyncophorus species (Plate3a). They also reported that the male is differentiated from the female using the length of the rostrum and presence or absence of tuft of hairs on the rostrum. Longer, curved rostrum without tuft of hairs identified female (Plate3b) while shorter less curved rostrum identified the male (Plate $3 \mathrm{c}$ ).

Four alternative substrates mainly agricultural waste (Plate 4) were used for the study:

1.Sugar Cane Tops (SCT) Saccharum officinarum (Cut Off tips of Sugar cane stem) (Shashina et al., 2009 and Giblin-Davies et al., 1989 also reported rearing of APW in SCT), (Production level in Nigeria 65,000 tons/year USDA Foreign Agricultural Services (2012/2013).

2.Spoilt Water Melon (SWM) (Citrullus lanatus).

3.Spoilt Pineapple (Ananascomosus) $(800,000$ metric tons/year produced in Nigeria (Makinde et al., 2011).

4. Paw paw (Carica papaya). Ripe pawpaw fruits are very perishable, and large quantities are disposed off yearly due to lack of or poor storage facilities (Awe 2011; Nwofia and Okwu 2012).

The experiment was designed using $4 \times 3$ Completely Randomized Design (CRD) whereby each of the four experimental units containing each of the respective culture media were replicated three times. Each replicate comprised ten larvae (10) with initial weight ranging from 4.11 to $4.24 \mathrm{~g}$ (Note: Dyar's rule on the instar stages is yet to be conventionally established as it relates to the Rhyncophorus phoenicis) making 30 larvae per experimental unit (Each of the waste was placed in 


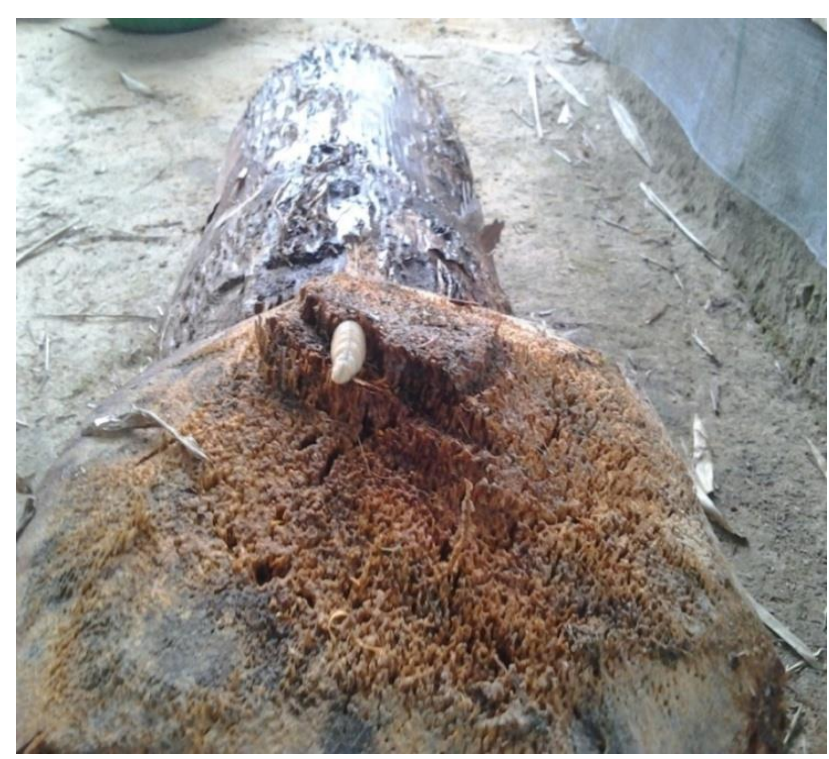

Plate 1. APW crawling out of the natural habitat: The raffia palm.

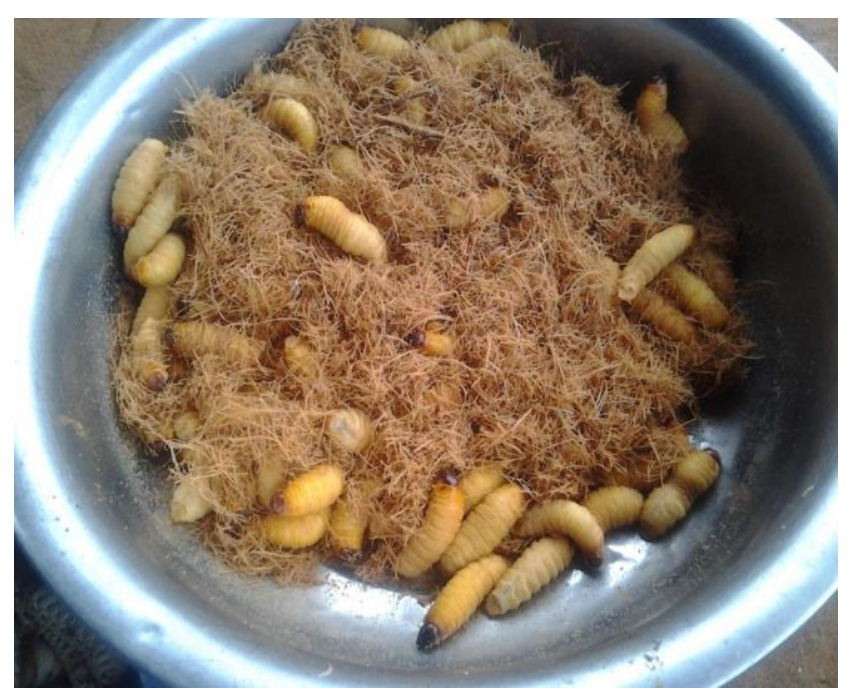

Plate 2. Larva in the chewed up trunk of Raffia palm.

plastic bowls of $30 \mathrm{~cm}$ diameters and height of $40 \mathrm{~cm}$ perforated at the bottom to let out moisture (these were later changed to sieves of the same size to facilitate draining of the moisture). The top of each bowl was covered with mosquito net to keep away insects and other parasites. Each bowl was kept on top of a bucket to collect juice or pulp resulting from feeding activity of the grub on the substrate. Fresh substrates (1 kilo/day) were used to replace old ones in each bowl every week to minimize accumulation of microbes and other parasites. During the 10 week period of the experiment, survivability was monitored by counting and recording number of larva alive in each substrate and taking record of mortality. a

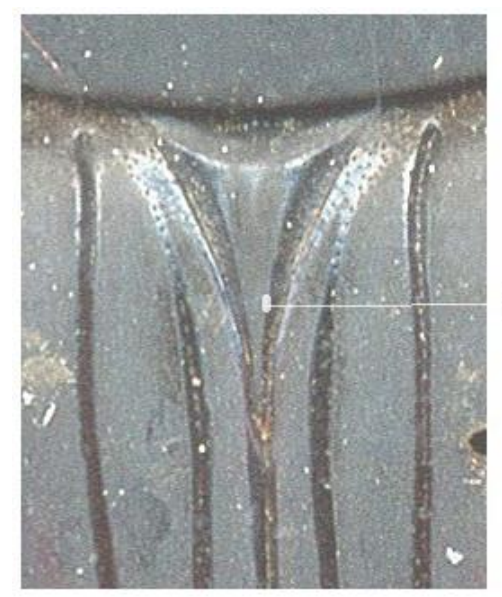

Acutely tapered scutellum

b

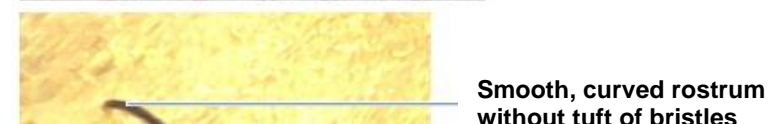

C

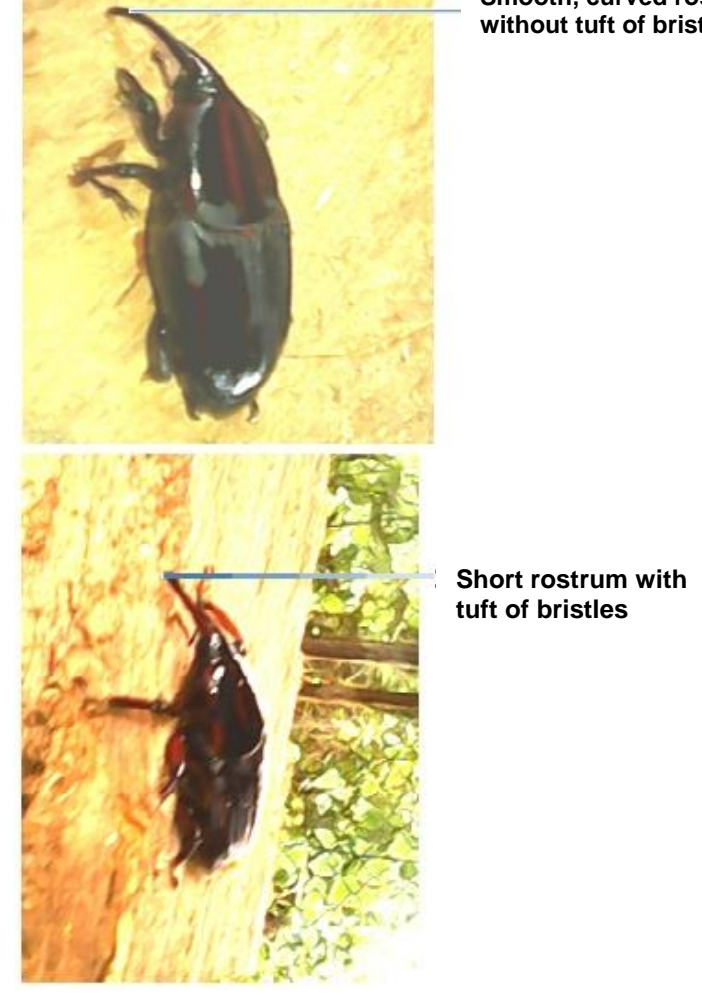

Plate 3a, b and c. Distinguishing features of Rhyncophorus phoenicis, Female and Male

$\%$ Survivability $=\frac{\text { No of larva alive }}{\text { No of larvae stocked }} \times 100$

The weight was monitored on weekly basis using Spring balance of brand name Labtech $(R)$ with model No BL7501 to the nearest $0.01 \mathrm{~g}$ while body length and width were taken to the nearest $0.01 \mathrm{~cm}$ on weekly basis using meter rule (Bong et al., 2008 and OEPP/EPPO 2007 also reported linear body measurements of the palm weevil). At the on-set of the experiment, samples of the substrates were taken to the Biochemistry Department 


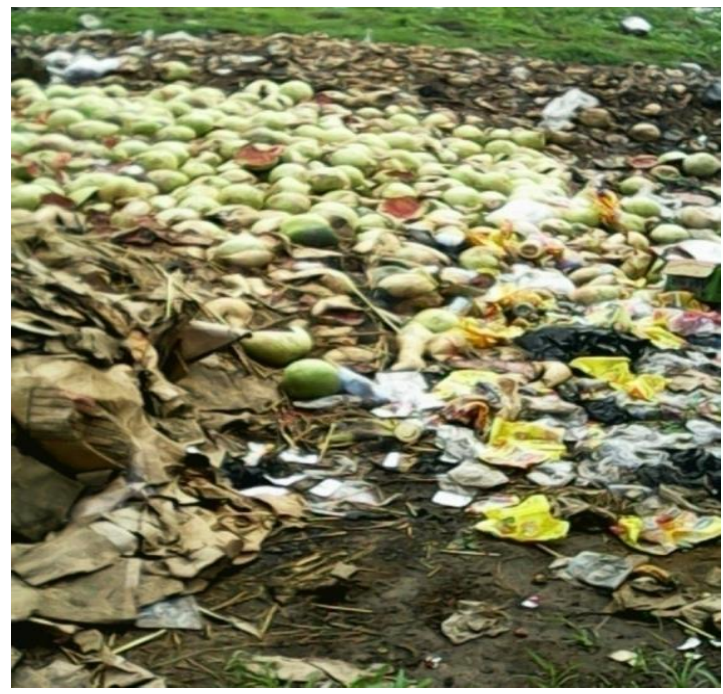

Plate 4. Dump site where SWM were collected.

Table 1. Proximate composition of the Fruits used as substrates in the study (\%).

\begin{tabular}{lcccc}
\hline \multirow{2}{*}{ Composition } & \multicolumn{4}{c}{ Substrates } \\
\cline { 2 - 5 } & SCT & SWM & SPA & RPP \\
\hline Moisture & $60.50 \pm 0.66$ & $87.00 \pm 2.80$ & $81.06 \pm 2.20$ & $82.40 \pm 0.02$ \\
Ash & $2.80 \pm 0.50$ & $2.80 \pm 1.34$ & $1.25 \pm 1.02$ & $0.28 \pm 0.01$ \\
DM & $25.42 \pm 1.56$ & $12.50 \pm 2.20$ & $18.94 \pm 0.64$ & $13.54 \pm 1.45$ \\
CHO & $15.82 \pm 2.20$ & $7.25 \pm 0.36$ & $15.66 \pm 1.23$ & $14.60 \pm 0.00$ \\
CP & $2.52 \pm 1.10$ & $1.05 \pm 0.02$ & $0.45 \pm 2.25$ & $0.82 \pm 1.15$ \\
EE & $0.96 \pm 0.06$ & $0.50 \pm 0.07$ & $0.16 \pm 0.00$ & $0.62 \pm 2.22$ \\
CF & $21.50 \pm 1.30$ & $1.50 \pm 0.30$ & $1.62 \pm 0.05$ & $1.28 \pm 2.51$ \\
\hline
\end{tabular}

DM, Dry matter, CP, Crude Protein, EE, Ether Extract, CF, Crude Fibre, CHO, Carbohydrate, $\mathbf{X}+\mathbf{A}$, means A is S.E. (S.E. means Standard error).

of Nnamdi Azikiwe University, Awka, for proximate analysis and at the end of the ten weeks period of the trial, nine samples of the larva (three from each replicate) were randomly picked and taken to the Biochemistry Department of Nnamdi Azikiwe University for proximate analysis to assess the effect of the substrate on the nutrient composition of the larva. Data generated on the weight and linear body measurement were analyzed using ANOVA for CRD while means were separated using Least Significant Difference (Little and Hills, 1978).

\section{RESULT AND DISCUSSION}

\section{Proximate composition of four different substrates}

The result of proximate composition of four different substrates is presented in Table 1 . The result showed that all the fruits have low protein and lipid content.

\section{Proximate composition of APW larva reared in the four different substrates}

Proximate composition of APW larva reared in the four different substrates (Plates 5, 6, 7 and 8) did not show significant difference though the numerical values of the Crude protein content appeared in the order SPA $(25.90 \%$ $>$ SWM $(22.80 \%)>$ SCT $(22.50)>$ RPP $(21.25 \%)$ (Table 2 and Figure 1). The findings agree with other literature report of the proximate composition of the larvae that grew completely in the raffia palm, though, the literature report has been fraught with inconsistencies. Banjo et al. (2006) reported crude protein content of APW from raffia palm to be $28.42 \%$ while Braide and Nwaoguikpe (2011) reported $71.63 \%$. For carbohydrate content, the range of 46.84 to $51.25 \%$ was in line with the report of $22.75 \%$ and $48.6 \%$ from Ekop et al. (2006) and (Banjo et al. 2006) respectively. Lipid content (17.26 to $18.42 \%)$ obtained in this study also agrees with the range of 


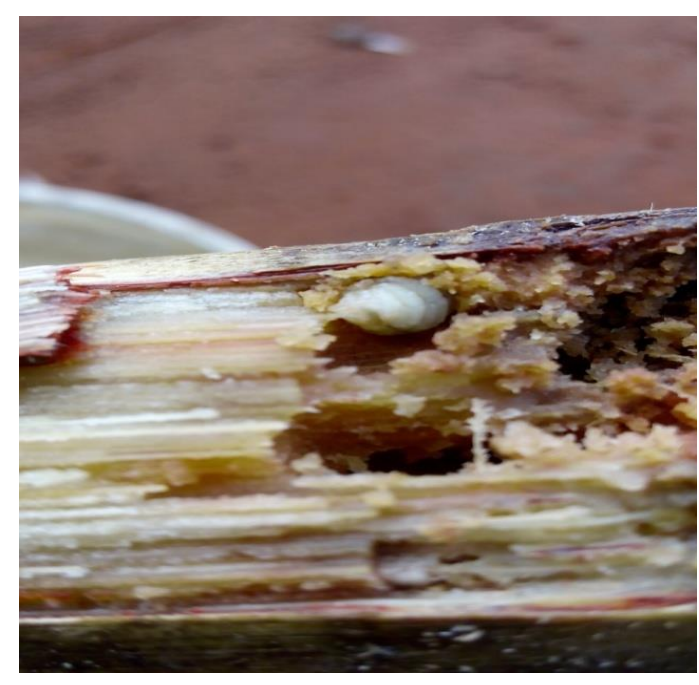

Plate 5a. APW Larva Boring into SCT substrate.

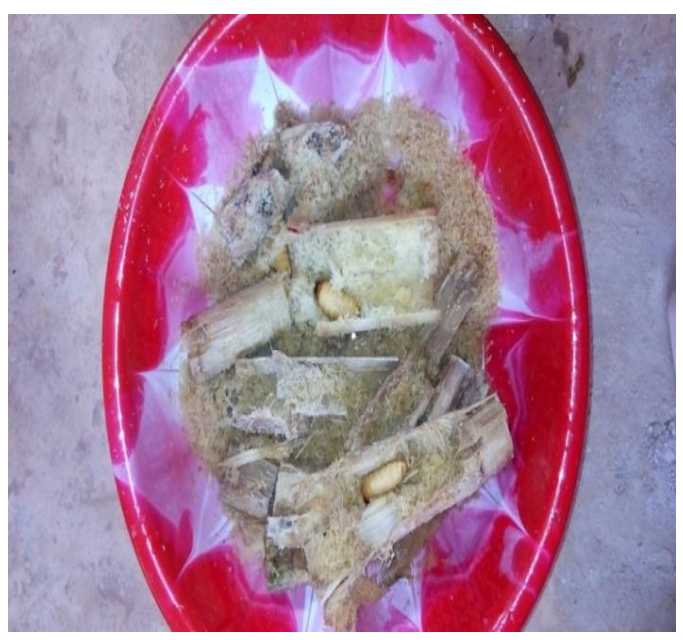

Plate 5b. larva shred sugar cane to pieces.

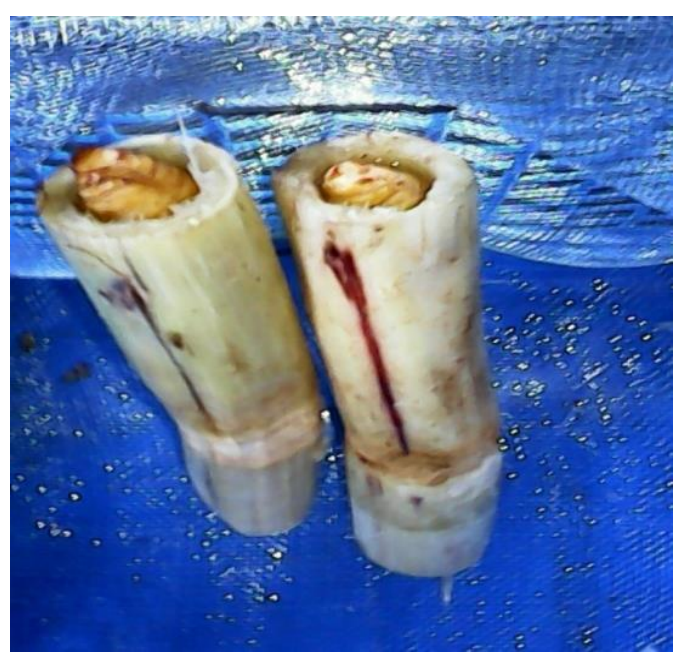

Plate 5c. Larva about to undergo pupation.

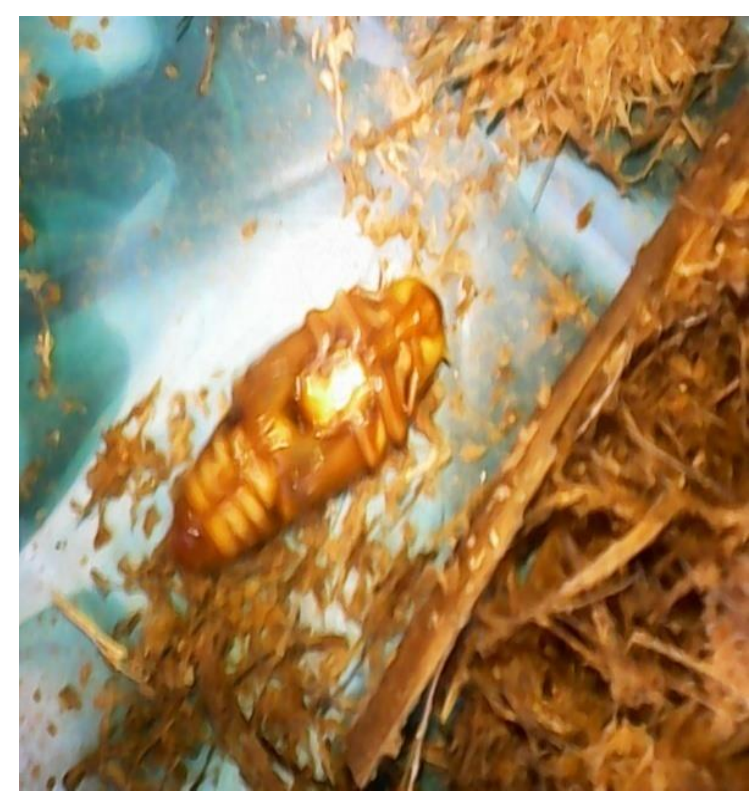

Plate 5d. Pupa in sugar cane top.

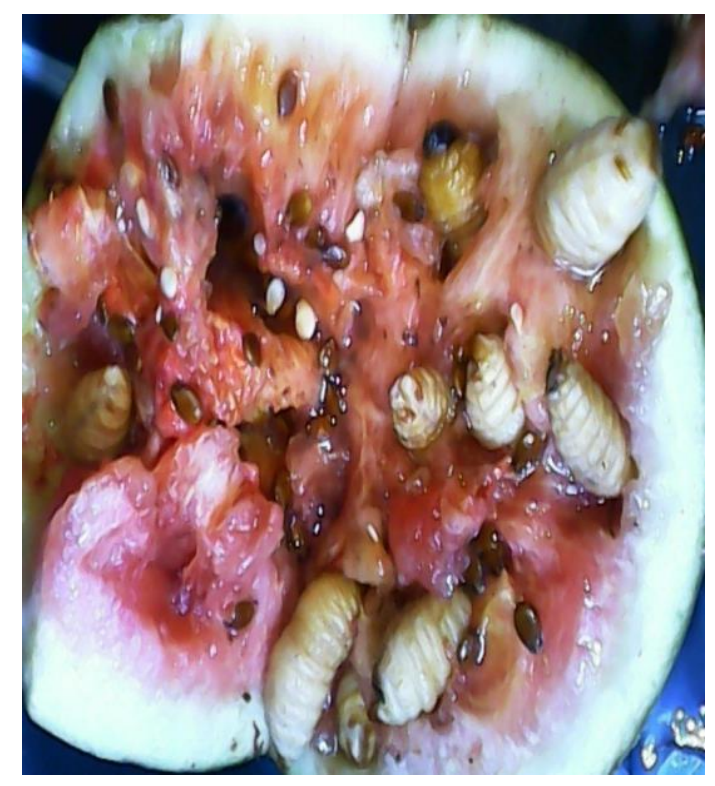

Plate 6. Larvae Boring into Spoilt water Melon (SWM) (Citrullus lanatus).

$8.25 \%$ (Braide and Nwaoguikpe, 2011) and $20.36 \%$ by Ekop et al. (2006).

\section{Survivability}

Result of survivability of the larva in each of the four substrates on trial is presented on the basis of weekly record in Figure 2 and percentage survivability in Figure 3. The result showed that percent survivability was 


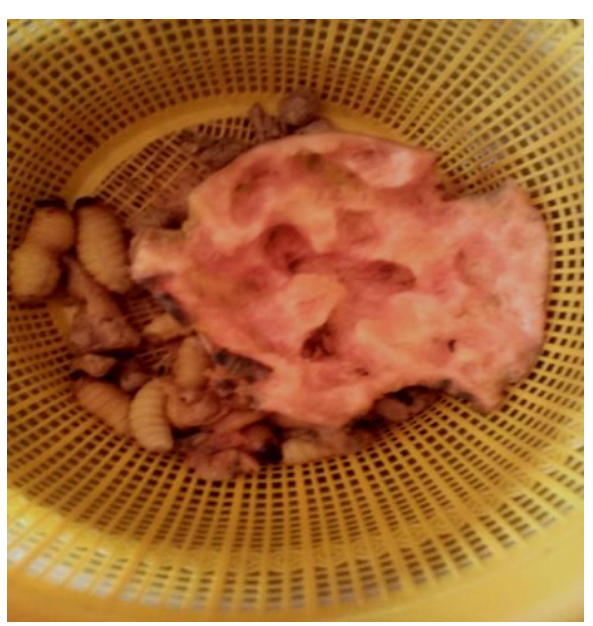

Plate 7a. Larva eating up Pawpaw fruit (Carica papaya).

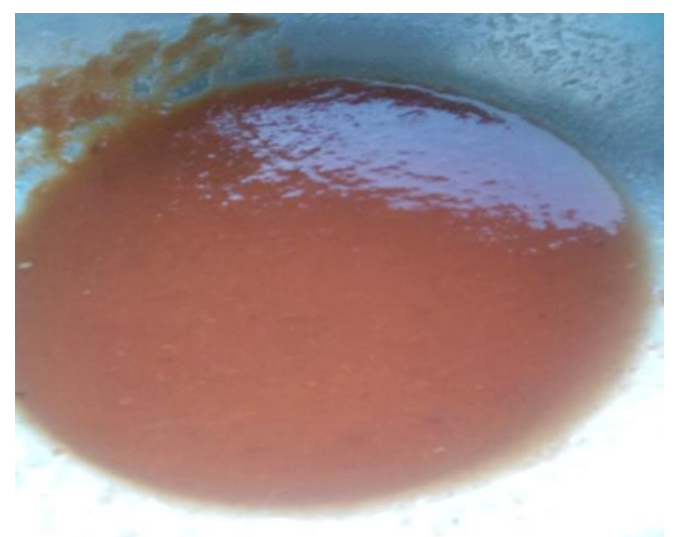

Plate 7b. Pulp collected in the bucket under the Papaya substrates as the larva feeds on it.

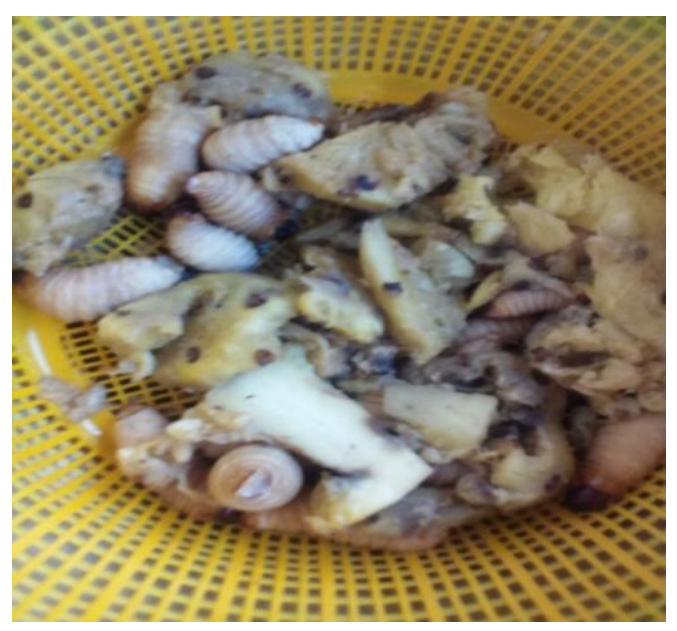

Plate 8. Larva eating up Spoilt Pineapple (SPA) (Ananas cosmosus).
Table 2. Proximate composition of APW reared in four different Substrate (\%).

\begin{tabular}{lcccc}
\hline \multirow{2}{*}{ Composition } & \multicolumn{4}{c}{ Substrate } \\
\cline { 2 - 5 } & SCT & SWM & SPA & RPP \\
\hline Moisture & 1.54 & 2.20 & 1.18 & 1.84 \\
DM & 98.4 & 98.80 & 98.82 & 98.16 \\
Ash & 5.22 & 5.82 & 5.34 & 4.76 \\
CHO & 48.50 & 47.48 & 46.84 & 51.25 \\
CP & 22.50 & 22.80 & 25.90 & 51.25 \\
EE & 3.82 & 4.46 & 3.48 & 3.50 \\
CF & 18.42 & 18.24 & 17.26 & 17.40 \\
\hline
\end{tabular}

DM, Dry matter, CP, Crude Protein, EE, Ether Extract, CF, Crude Fibre, $\mathrm{CHO}$, Carbohydrate.

highest in SCT (96.7\%), followed by SPA 96.2\%, 94.6\% for SWM and least in larva reared on RPP (66.7\%). Shashina et al. (2009) reported that sugar cane is the best medium for the Red Palm weevil. Giblin-Davies et al. (1989) also reported that sugar cane is a good substitute for rearing of Rhyncophorus cruenatus. However, literature report on rearing of the larva in any of these substrates and their percent survivability in such substrates is scarce. It appears that the SCT has textural characteristics and nutrient content similar to the raffia palm. Akpabio et al. (2012) reported the nutritional composition of exudates produced by puncturing of the raffia palm trunk to be rich in carbohydrate $(85.4 \%)$ and calorific value of $(375 \mathrm{kcal} / 100 \mathrm{~g})$ as well as high content of mineral $(\mathrm{mg} / 100 \mathrm{~g})$ of the exudates to include Calcium (55.31), Magnesium (26.60), Sodium (23.63), Potassium (20.95), Manganese (8.54), Cobalt (4.77) and Iron (4.57). High Sodium content of the raffia palm pith was also reported by Reynolds et al. (2009). For the Sugar cane Malik (2016) reported $111.13 \mathrm{~kJ}$ (26.56 kcal) Energy, $27.51 \mathrm{~g}$ Carbohydrates, $0.27 \mathrm{~g}$ Protein, $11.23 \mathrm{mg}$ Calcium (1\%), Iron $0.37 \mathrm{mg} \mathrm{(3 \% ),} \mathrm{Potassium} 41.96 \mathrm{mg}$ (1\%), Sodium $17.01 \mathrm{mg}$ (1\%). The rich energy, mineral and similar textural characteristics of the sugar cane in relation to the raffia palm pith may be responsible for the better performance of the weevil in SCT.

\section{Growth Performance}

The body measurements of APW larvae reared on four different substrates are presented in Table 3 . The range of Mean body weight of APW larva $(6.94 \pm 1.04$ to $8.33 \pm$ $1.10 \mathrm{~g})$, mean body length $(4.47 \pm 1.00$ to $5.60 \pm 0.90$ $\mathrm{cm})$ and body width $(1.75 \pm 1.21$ to $1.95 \pm 1.12 \mathrm{~cm})$ obtained in this study is comparable to other findings on the weight, body length and body width of the larvae obtained from its natural habitat i.e. the raffia palm. Tambe et al. (2013) reported weight range of 3.67 to 4.26 $\mathrm{g}$ and average body length of $1.09 \mathrm{~mm}$ and width of 0.43 $\mathrm{mm}$ for Rhyncophorus phoenicis reared in the Southwest 


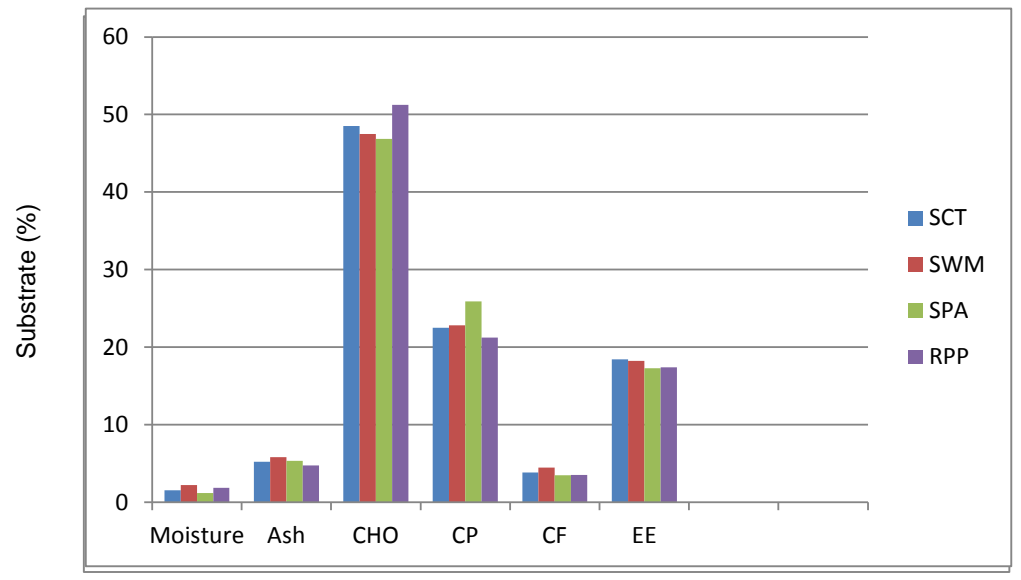

Figure 1. Graphical presentation of the Proximate Composition of APW Reared in Four Different Substrate (\%).

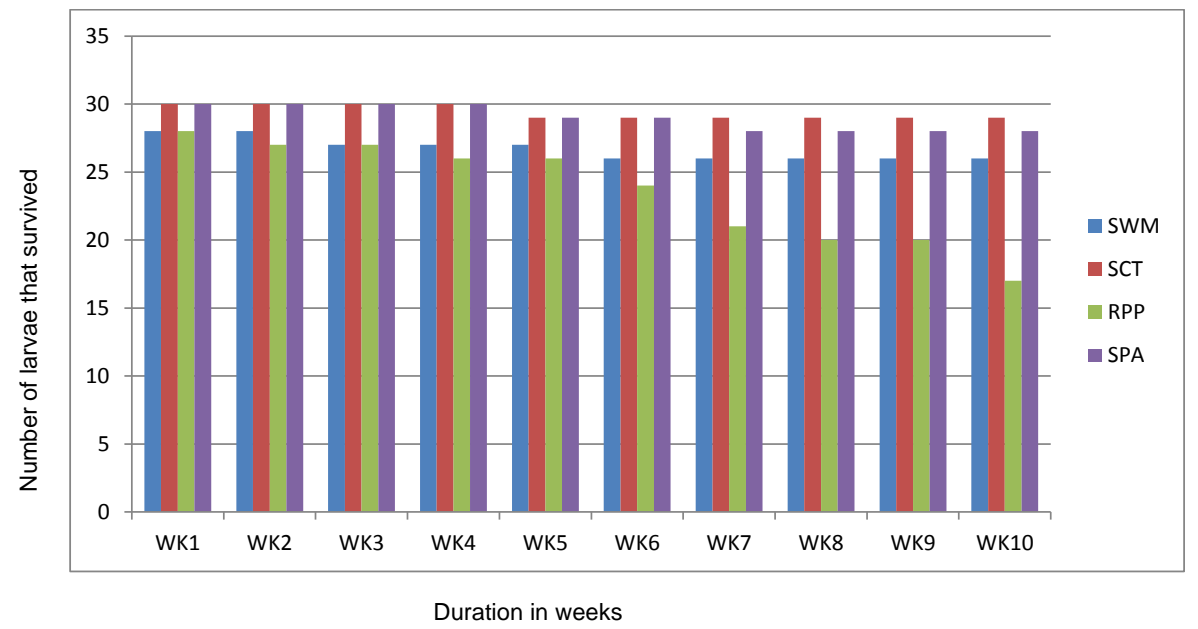

Figure 2. Weekly Chart of Survival of APW in each of the Substrates within the Ten Week Period.

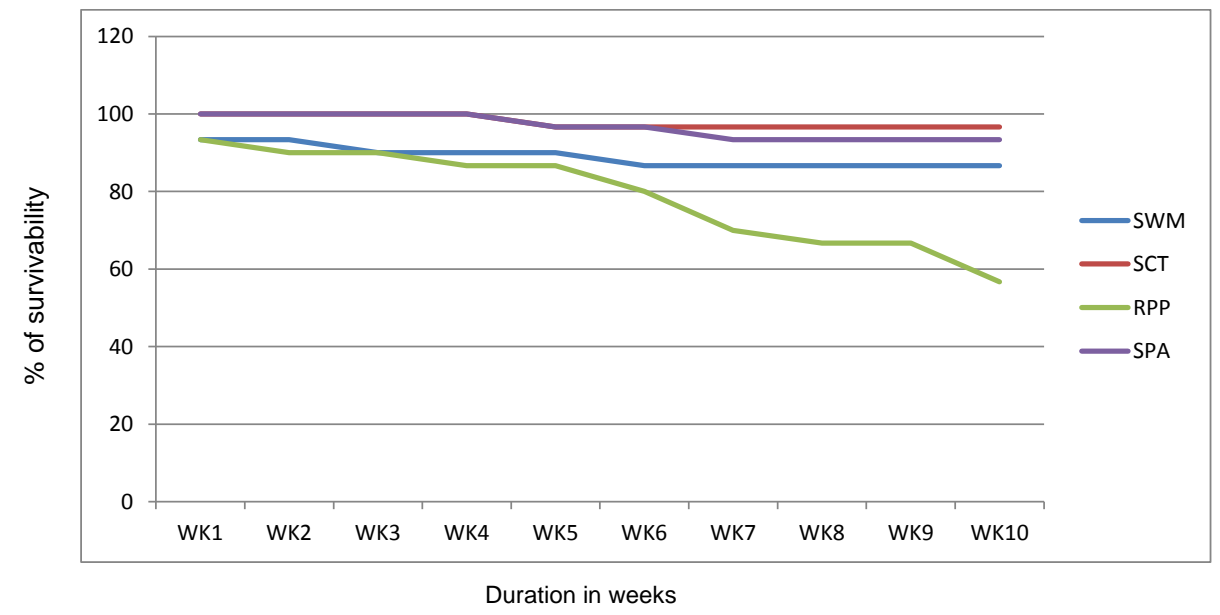

Figure 3. Percentage Survivability of APW larva in each of the Substrates. 
Table 3. Body measurements of APW Larvae reared on Four Different Substrates.

\begin{tabular}{lccc}
\hline \multirow{2}{*}{ Composition } & \multicolumn{3}{c}{ Measurements } \\
\cline { 2 - 4 } SCT & $\mathbf{W t} \mathbf{( g )}$ & $\mathbf{B L}(\mathbf{c m})$ & BW_(cm) \\
Initia & & & \\
Final & $4.20 \pm 1.20$ & $3.60 \pm 2.11$ & $1.30 \pm 0.80$ \\
MI & $8.33 \pm 1.10$ & $5.60 \pm 0.90$ & $1.95 \pm 1.21$ \\
& $4.13 \pm 0.11^{\mathrm{a}}$ & $2.00 \pm 1.30^{\mathrm{a}}$ & $0.65 \pm 0.80^{\mathrm{a}}$ \\
SPA & & & \\
Initia & & & \\
Final & $4.20 \pm 0.96$ & $3.62 \pm 1.28$ & $1.26 \pm 2.14$ \\
MI & $8.31 \pm 1.32$ & $5.26 \pm 1.42$ & $1.80 \pm 1.46$ \\
& $4.11 \pm 0.31^{\mathrm{b}}$ & $1.64 \pm 1.20^{\mathrm{b}}$ & $0.54 \pm 0.85^{\mathrm{b}}$ \\
RPP & & & \\
Initia & & & $1.34 \pm 0.90$ \\
Final & $4.24 \pm 1.20$ & $3.57 \pm 0.78$ & $1.75 \pm 1.21$ \\
MI & $6.94 \pm 1.04$ & $4.47 \pm 1.00$ & $0.41 \pm 0.60^{\mathrm{c}}$ \\
SWM & $2.70 \pm 0.06^{\mathrm{c}}$ & $0.90 \pm 1.00^{\mathrm{c}}$ & \\
Initia & & & $1.27 \pm 0.00$ \\
Final & $4.20 \pm 0.90$ & $3.52 \pm 0.68$ & $1.77 \pm 1.20$ \\
MI & $8.23 \pm 1.10$ & $5.32 \pm 1.20$ & $0.50 \pm 0.92^{\mathrm{b}}$ \\
\hline
\end{tabular}

Wt, Weight, BL, Body length, BW, Body length and MI, Mean Increase, $X+A-A=S . E$. (Standard error). ${ }^{a, b, c}$, Means with similar superscripts are not significantly different.

Cameroun. Adeyeye and Aye (2008) reported mean body weight of $15.7 \mathrm{~g}$, mean body length of $9.47 \mathrm{~cm}$ and mean body diameter of $2.0 \mathrm{~cm}$ for Rhyncophorus phoenicis collected from raffia palm in Ekiti State, Nigeria. Bong et al. (2008) reported weight of 1.50 to $2.40 \mathrm{~g}$ for Rhyncophorus shach and OEPP/EPPO (2007) reported the range of $R$. ferrugineus body length of 44 to $57 \mathrm{~mm}$ and width of 22 to $25 \mathrm{~mm}$.

\section{Conclusion}

Alternative means of culturing edible insect remains a panacea to its sustainability and increased productivity. This research has established the possibility of rearing the African Palm weevil larva on spoilt fruits or fruit wastes. Further studies will now be undertaken to assess any further fortification of the waste fruit that will improve the growth and pupation of the larva in captivity. Besides, the growth changes of the larvae will be monitored alongside the moulting process to assess compliance/non-compliance with Dyar's law.

\section{CONFLICT OF INTEREST}

The authors declare that they have no conflict of interest.

\section{REFERENCES}

Adeyeye, E. I., \& Aye P.A. (2008). The Chemical Composition and Functional Properties of the Flesh and Viscera of Raffia palm tree grub (Rhynchophorus phoenicis). Pakistan Journal of Nutrition 7 (1), 121-128.

Akpabio, U. D., Akpakpan, A. E., Udo, U. E., \& Essien, U. C. (2012). Physicochemical characterization of exudates from Raffia Palm (Raphia hookeri). Advances in Applied Science Research, 3 (2), 838-843.

Awe, S. (2011) Production and Microbiology of Pawpaw (Carica papaya L) Wine. Current Research Journal of Biological Sciences 3(5), 443-447.

Banjo, A. D., Lawal, O. A., Songonuga, E. A. (2006). The nutritional values of fourteen species of edible insects in South Western Nigeria. African Journal of Biotechnology 5(3), 208-301.

Bong, C. F. J., Er, C. C., Yiu, P. H., \& Rajan, A. (2008). Growth Performance of the Red-Stripe Weevil Rhynchophorus schach Oliv. (Insecta: Coleoptera: Curculionidae) on Meridic Diets. American Journal of Agricultural and Biological Sciences, 3(1), 403-409.

Ebenebe, C. I. Anizoba, M. A., Okeke, J. J., Okpoko, V. O, Madu, B., \& Uzocukwu C. (2007). The Potentials of Palm Grub (Rhynchophorus phoenicis) and manure grub (Rhynchophorus ferrugineus) as Food and Feed. Journal of Advancement in Medical and Pharmaceutical Research. 1 (4), 41-45.

Ebenebe, C. I., \& Okpoko, V. O. (2015). Edible Insect Consumption in the southeastern Nigeria. International Journal of Science and Engineering, 6(6). https://www.academia.edu/15308898/Edible_Insect_Consum ption_in_the_South_Eastern_Nigeria.

Ebenebe, C. I., \& Okpoko, V. O. (2016). Preliminary studies on Alternative Substrate for Multiplication of African Palm weevil 
(Rhynchophorus phoenicis) under captive management. Journal of Insect for Food and Feed, 2(3),171-177

Edijala, T. K., Eghogbo, O., Anigboro, A. A. (2009). Proximate Composition and cholesterol concentrations of Rhyncophorus phoenicis and Orytces monocerus larvae subjected to Different Heat Treatments. African Journal of Biotechnology, 8(10), $2346-2348$.

Ekpo, K. E., \& Onigbinde, A. O. (2004) Pharmaceutical Potentials of Rhyncophorus phoenicis larval oil. Nigerian Annals of Natural Sciences, 9(2), 28-36.

El-Shafie, H. A. F., Faleiro, J. R., Abo-El- Saad, M. M., Aleid, S. M. (2013). Meridic diet for laboratory rearing of Red Palm Weevil, Rhynchophorus ferrugineus (Coleoptera: Curculionidae). Academic Journal of Scientific Research and Essays, 8(39), 1924-1932.

FAO (1991). State of Forest and Tree genetic resources in dry zone southern Africa Development Community Countries. Rome.

FAO/ WUR (2013). Food and Agriculture organization and Wagening University Research Centre. Edible Insect: Future Prospect for Food and Feed Security. FAO Forestry Paper 171. Edited by Arnold Van Huis, Joost Van Litterbeck, Hammett Klunder, Ester martens, Afton Hallowan, Giula Muir and Paul Vantomme

Giblin-Davis, R. M., Gerber, K., \& Griffith, R. (1989). Laboratory Rearing of Rhynchophorus cruenstatus and Rhynchophorus palmarum (Coleoptera: Curulionidae). Florida Entomology, 72, 480-488.

Giblin Davis, R. M., Faleiro, J. R., \& Jacas, J. A. (2013) Biology and Management of Palm weevils. University of Florida/ IFAS Fort Lauderdale Research and Education Centre. www.cisr.urc.edu./.../giblindavisrobin-biology-an. Accessed on the 13th August, 2015.

Hoddle, S. M. (2013). Entomophagy: Farming Palm weevils for Food.University of California, Riverside for Invasive Species Research Report. www.cisr.ucr.edu

Kaakeh, W., Aboul-Anour, M., \& Khamis, A. A. (2001). Mass rearing of the red palm weevil, Rhynchophorus ferrugineus Oliv., on sugarcane and artificial diets for laboratory studies. Pp. 344-357. In Proceedings of the Second International Conference on Date Palm (refereed), AI-Ain, UAE.
Malik, K. (2016). Six Health Benefits of Sugarcane Juice: A Promise of Good Health New Delhi Television News. http://www.ndtv.com/

Makinde, O. A., Odeyinka, S. M., \& Ayandiran, S. K. (2011). Simple and quick method for recycling pineapple waste into animal feed. Livestock Research for Rural Development, 23(9).

Malaisse, F. (1997). Se nounvir en Foret Claire Africaine: Approche eclogique et nutionelle Pays-Bays. Presses agronomiques de Gembloux.

Mmadubuike, F. N. (2000). Microlivestock as Food and Feed. Invited Paper Presented at the $5^{\text {th }}$ Annual Conference of Animal Science Association of Nigeria. 19th-22nd September. Rivers State University of Science and Technology Port Harcourt.

Nwofia, G. E., \& Okwu, Q. U. (2012). Studies on nutritive characteristics and variability in pawpaw (Carica papaya L.) Pakistan Journal of Nutrition 11(10), 859-864.

OEPP/EPPO (2007). European and Mediteranean Plant Protection Organization. Bulletin 37, 571-579.

Okoro, F. U. (2000). "Adoption of Rabbitry Technologies among Farmers in Okigwe Agricultural Zone of Imo State", Nigeria. Proceedings of 25th Conference of Nigerian Society of Animal production 19th-23rd March, Michael Okpara University, Umudike, Abia State, Nigeria. Pp. 414 -416.

Reynolds, V., Lloyd, A. W., Babweteera, F., \& English, C. J. (2009). Decaying Raphia farinifera palm trees provide a source of sodium for wild chimpanzees in the Budongo Forest, Uganda. PLoS One, 4(7), e6194.

Tambe, J. T., Riolo, P., Okolle, J. N., Pietro, N. I., Fanciulli, P., \& Dallah, R. (2013)Sexual size differences and colour polymorphism of Rhynchophorus phoenicis in the Southwest region of Cameroon. Bulletin of Insectology, 66(1), 153-159. 